\title{
PERANCANGAN SISTEM INFORMASI STOK BARANG PADA GUDANG E9 PLUIT JAKARTA UTARA
}

\author{
Masrukha $^{1}$, Sri Mardiyati ${ }^{2}$, Halimatusha'diah ${ }^{3}$ \\ Program Studi Teknik Informatika, Fakultas Teknik dan Ilmu Komputer, \\ Universitas Indraprasta PGRI \\ Jalan Raya Tengah No 80, Kelurahan Gedong, Pasar Rebo, Jakarta Timur \\ Masrukha107@gmail.com ${ }^{1}$, srimardiyati05@gmail.com², halimatushadiah31@gmail.com
}

\begin{abstract}
Abstrak
Tujuan Perancangan Aplikasi Stok Barang secara komputerisasi ini adalah untuk mempermudah dalam mengelola data yang terdapat pada Gudang E9 dengan mengumpulkan data-data untuk menganalis dan merancang aplikasi stok barang, selain itu perancangan dapat mengurangi masalah human error dalam pendataan barang pada Gudang E9 dapat terselesaikan dengan cepat, tepat, akurat guna mengefisienkan waktu pekerjaan. Metode penelitian yang digunakan dalam aplikasi ini adalah studi lapangan yaitu pengamatan langsung, wawancara dengan pihak terkait dengan melakukan dokumentasi untuk mendapatkan informasi yang dibutuhkan. Pada penelitian ini telah dirancang sebuah Aplikasi Stok Barang dimana dalam membangun sistem ini memanfaatkan database MySQL sebagai penyimpanan dan aplikasi desktop (Netbeans) yang berbasis Java. Dari hasil penelitian, dengan adanya hasil kinerja sistem terkomputerisasi sangat efektif jika diterapkan, dengan sistem pencari data yang berhubungan dengan pendataan barang karyawan.
\end{abstract}

Kata Kunci: Aplikasi, Stock Barang, Java, Neatbeans, MySQL

\begin{abstract}
The purpose of computerized Stock Application Design is to facilitate in managing the data contained in Warehouse E9 by collecting data to analyze and design stock applications, in addition, design can reduce human error problems in the collection of goods in Warehouse E9 can be resolved quickly, precisely, accurately to streamline work time. The research method used in this application is field studies i.e. direct observation, interviews with related parties by doing documentation to get the required information. In this research has been designed a Stock Goods Application where in building this system utilizes MySQL databases as storage and desktop applications (Neatbeans)based on Java. From the results of the study, with the results of computerized system performance is very effective if applied, with a data search system related to the collection of employee goods.
\end{abstract}

Keyword: Application, Stock Of Goods, Java, Neatbeans, MySQL

\section{PENDAHULUAN}

Seiring dengan perkembangan teknologi informasi yang semakin maju berpengaruh penting di dalam perusahaan. Informasi yang dibutuhkan haruslah akurat dan dapat diandalkan sehingga dapat memberikan nilai lebih bagi pengguna informasi tersebut. Tidak dapat dipungkiri lagi bahwa kebutuhan akan informasi saat ini menjadi prioritas utama bagi para pengambil keputusan dalam mengelola perusahaan. Berdasarkan realita tersebut, maka kebutuhan informasi pada perusahaanperusahaan saat ini telah menjadi kebutuhan utama. Oleh karena itu, informasi yang biasanya didapatkan dengan cara tradisional atau manual, sudah tidak dapat digunakan lagi secara maksimal dalam memenuhi kebutuhan perusahaan.

Perkembangan teknologi saat ini telah banyak membantu kinerja manusia dalam mengerjakan tugasnya sehingga menjadi lebih mudah, cepat, dan hasilnya yang memuaskan. Salah satu teknologi ini adalah komputer dalam sebuah instansi saat ini, komputer merupakan sebuah alat atau sarana yang sangat dibutuhkan untuk membantu dalam menyelesaikan pekerjaan perusahaan di bidangnya masing-masing. Pada Gudang E9 Pluit Jakarta Utara, saat ini sistem persediaan gudang yang berjalan masih menggunakan proses manual sehingga banyak kekurangan dalam kegiatan pencatatan transaksi keluar masuknya ketersedian barang barang, dan penyusunan laporan, hal ini 
dapat menyebabkan kinerja perusahaan menjadi terhambat dan belum mampu menunjang segala kebutuhan yang diinginkan perusahaan.

Berdasarkan permasalahan yang ada, oleh karena itu diusulkan untuk merancang sistem aplikasi stok barang berbasis java. Dalam pembuatan sistem aplikasi stok barang berbasis java ini menggunakan Netbeans IDE 8.2 dan MySQL untuk perancangan basis datanya. Diharapkan dengan menggunakan aplikasi sistem stok barang berbasis java ini dapat mempermudah dan mempercepat kinerja karyawan gudang serta dapat mengontrol jumlah persediaan barang yang ada.

\section{PENELITIAN RELEVAN}

Dalam rangka mendapatkan hasil yang baik, selain melakukan penelitian secara langsung peneliti juga melakukan kajian pustaka. Dari hasil penelitian yang telah dilakukan, beberapa hasil acuan adalah :

Penelitian yang dilakukan oleh (Wicaksono \& Samsoni, 2021) dengan judul penelitian "Perancangan Aplikasi Sistem Inventory Gudang di Bank BTN Cabang Depok".peneliti melakukan uji coba pembaruan sistem stok barang di Bank BTN menggunakan aplikasi stock barang berbasis web menggunakan bahasa pemrograman PHP dan database MySQL, hasil dari aplikasi yang dibuat oleh peneliti diatas stok barang untuk mengatur pendataan barang dirasakan lebih mudah karena karyawan dapat melihat data langsung dari sistem aplikasi stok barang tersebut.

\section{METODE PENELITIAN}

Metode yang digunakan dalam penelitian ini adalah metode grounded (grounded research). Menurut (Ismail, 2009) menjelaskan bahwa grounded reseach adalah suatu metode penelitian yang mendasarkan diri kepada fakta dan penggunaan analisis perbandingan, yang bertujuan untuk mengadakan generalisasi empiris, menerapkan konsep-konsep, membuktikan teori, dan mengembangkan teori, di mana pengumpulan data dan analisa data berjalan pada waktu yang bersamaan.

Metode Pengumpulan Data antara lain :

1. Studi lapangan

a. Obsevasi

Observasi merupakan salah satu cara mengumpulkan data yang diperlukan dengan cara melakukan pengamatan dan meneliti secara langsung gejala atau peristiwa yang diselidiki oleh peneliti.

b. Wawancara

Wawancara merupakan proses memperoleh keterangan untuk tujuan penelitian dengan cara melakukan tanya jawab kepada responden ataupun pihak-pihak yang terkait.

2. Studi Pustaka

Untuk memperoleh data sekunder, peneliti melakukan studi pustaka, yaitu dengan mempelajari atau membaca pendapat ahli yang berhubungan dengan permasalahan yang akan diteliti.

\section{HASIL DAN PEMBAHASAN}

Analisis Permasalahan

Analisis masalah yang peneliti lakukan yaitu identifikasi terhadap masalah yang terjadi di Gudang E9 Pluit Jakarta Utara. Peneliti menemukan permasalahan yang ada di bagian stock barang yaitu proses perhitungan stok barang yang masih menggunakan sistem manual, yaitu dengan cara mencari satu persatu arsip yang telah di simpan. Sehingga membuat waktu kerja tidak efisien. Untuk memudahkan pihak Gudang E9 Pluit Jakarta Utara peneliti membuat program sistem stock barang dan peneliti menggunakan UML untuk merancang sistem itu. Di dalam analisis masalah peneliti menganalisa sistem yang sedang berjalan dan sistem yang diusulkan dapat digambarkan pada activity diagram. 


\section{Alternatif Penyelesaian Masalah}

Penyelesaian masalah yang peneliti gunakan dalam menyelesaikan masalah yang ada yaitu mengganti sistem yang berjalan manual dengan sistem yang terkomputerisasi berbasis desktop. Secara umum, sistem yang akan dibangun yaitu sistem stock barang yang terintegrasi agar memudahkan dalam mengolah data barang seperti pengelolaan data, kode barang, nama barang, jenis barang, dan jumlah barang. Sehingga di harapkan tidak akan terjadi lagi prosedur pencarian arsip yang menyita waktu dan juga meminimalisir suatu kesalahan dalam memproses data serta pihak Gudang E9 Pluit Jakarta Utara dapat bekerja lebih optimal.

UML (Unified Modelling Language) adalah salah satu standar bahasa yang banyak digunakan didunia industri untuk mendefinisikan requirement, membuat analisis dan desain, serta menggambarkan arsitektur dalam pemrograman berorientasikan objek. (A.S., Rosa dan Shalahuddin, 2016)

\section{Use Case Diagram Sistem yang diusulkan}

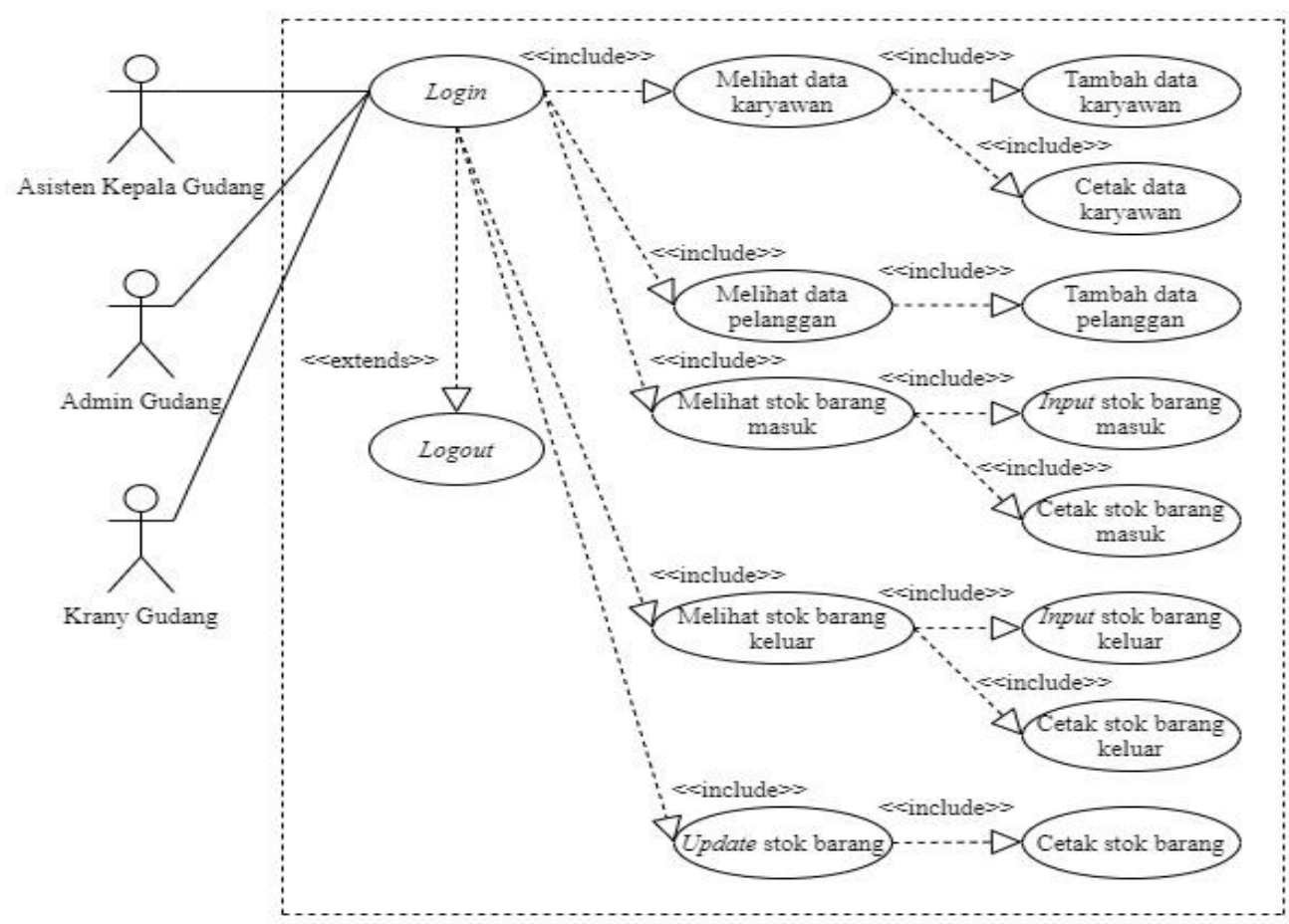

Gambar 1. Use Case Diagram 


\section{Class Diagram}

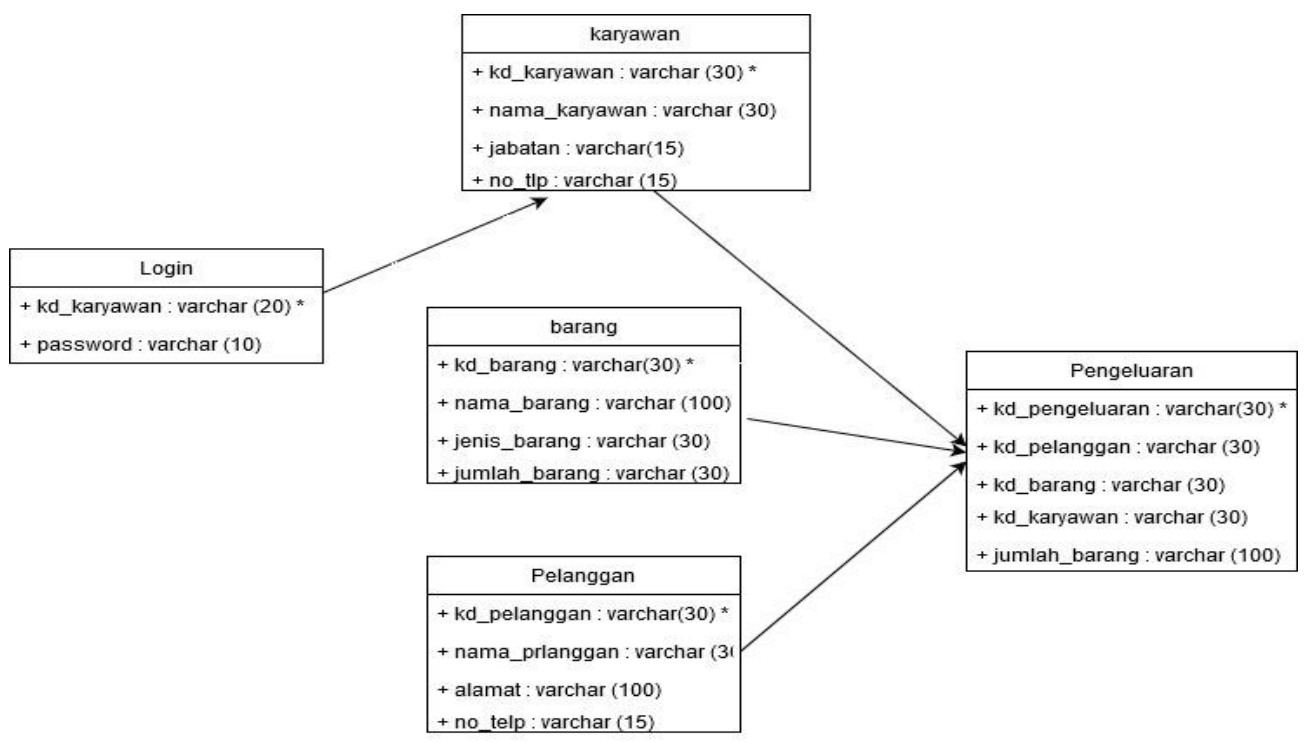

Gambar 2. Class Diagram

\section{Tampilan Aplikasi}

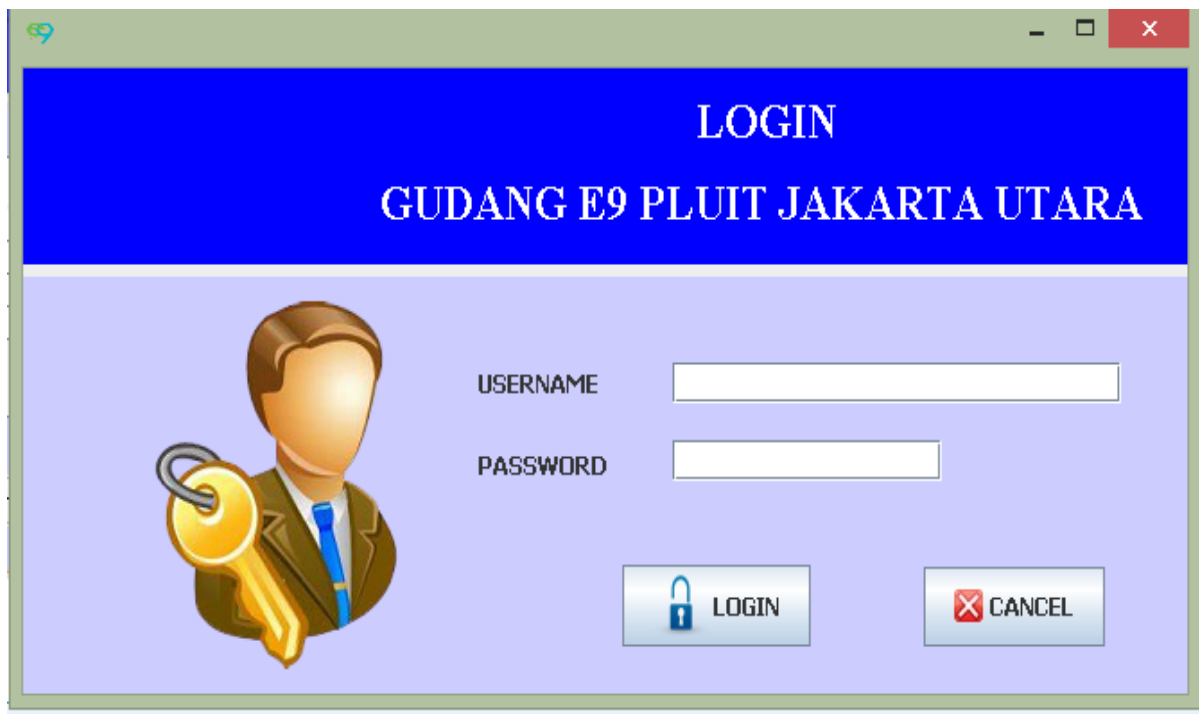

Gambar 3. Tampilan Login

Gambar tampilan login diatas merupakan tampilan awal masuk aplikasi stok barang yang dapat diakses oleh pemilik dan juga karyawan. 


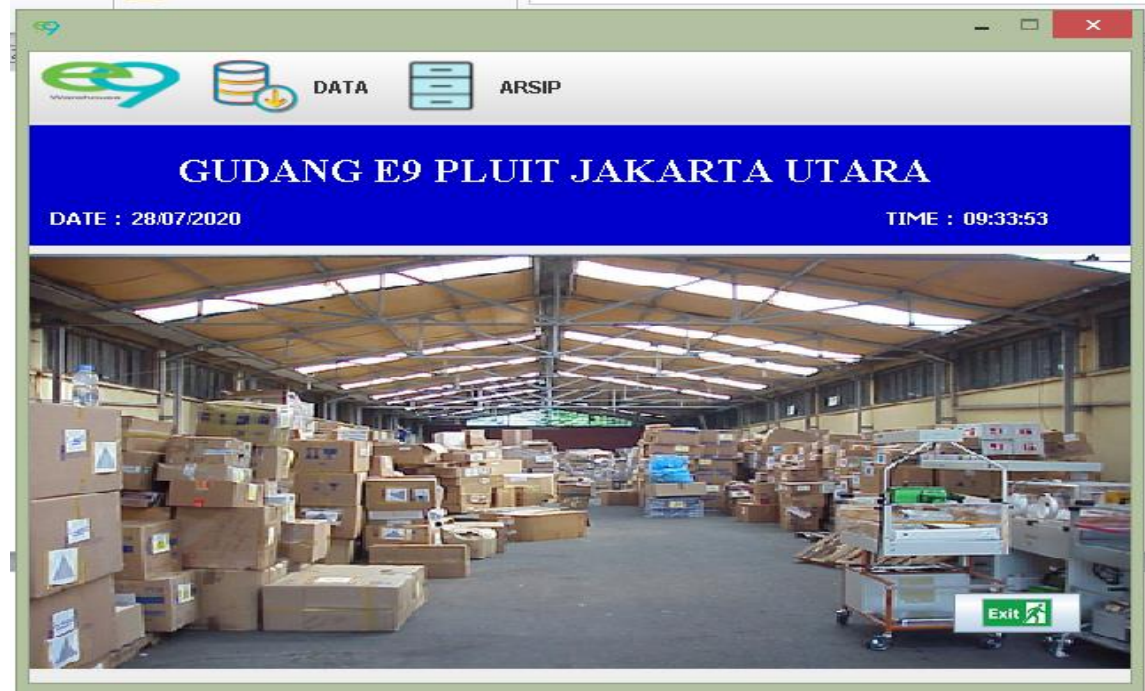

Gambar 4. Tampilan Menu Utama

Gambar menu utama merupakan tampilan awal dari semua sistem yang akan dijalankan. Pada pilihan data terdapat menu tampilan data barang masuk, tampilan data barang keluar, tampilan data karyawan, tampilan data pelanggan, dan laporan stok barang. Sedangkan pada pilihan arsip terdapat laporan barang masuk, laporan barang keluar, laporan karyawan, dan laporan pelanggan.

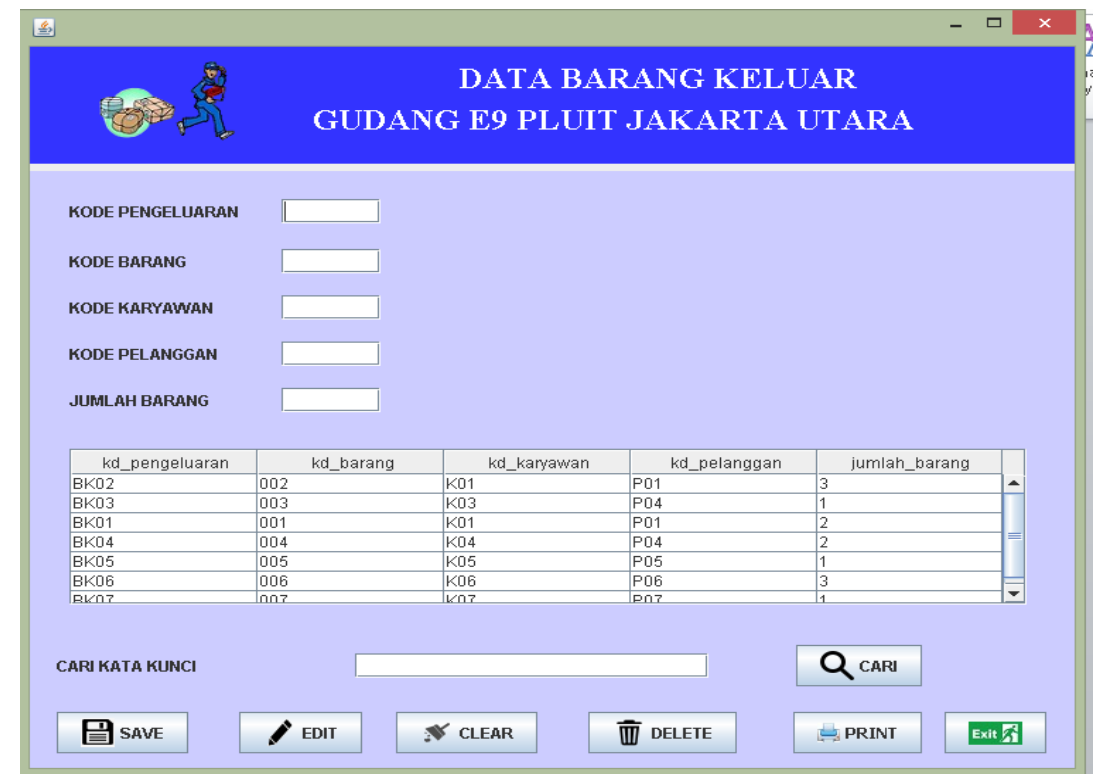

Gambar 5. Tampilan Data Barang Keluar

Tampilan barang keluar digunakan untuk melakukan pendataan barang yang akan disimpan kedalam sistem aplikas stok barang dan juga kedalam sistem database secara otomatis, data barang keluar juga sudah otomatis menghitung stok barang yang ada. 


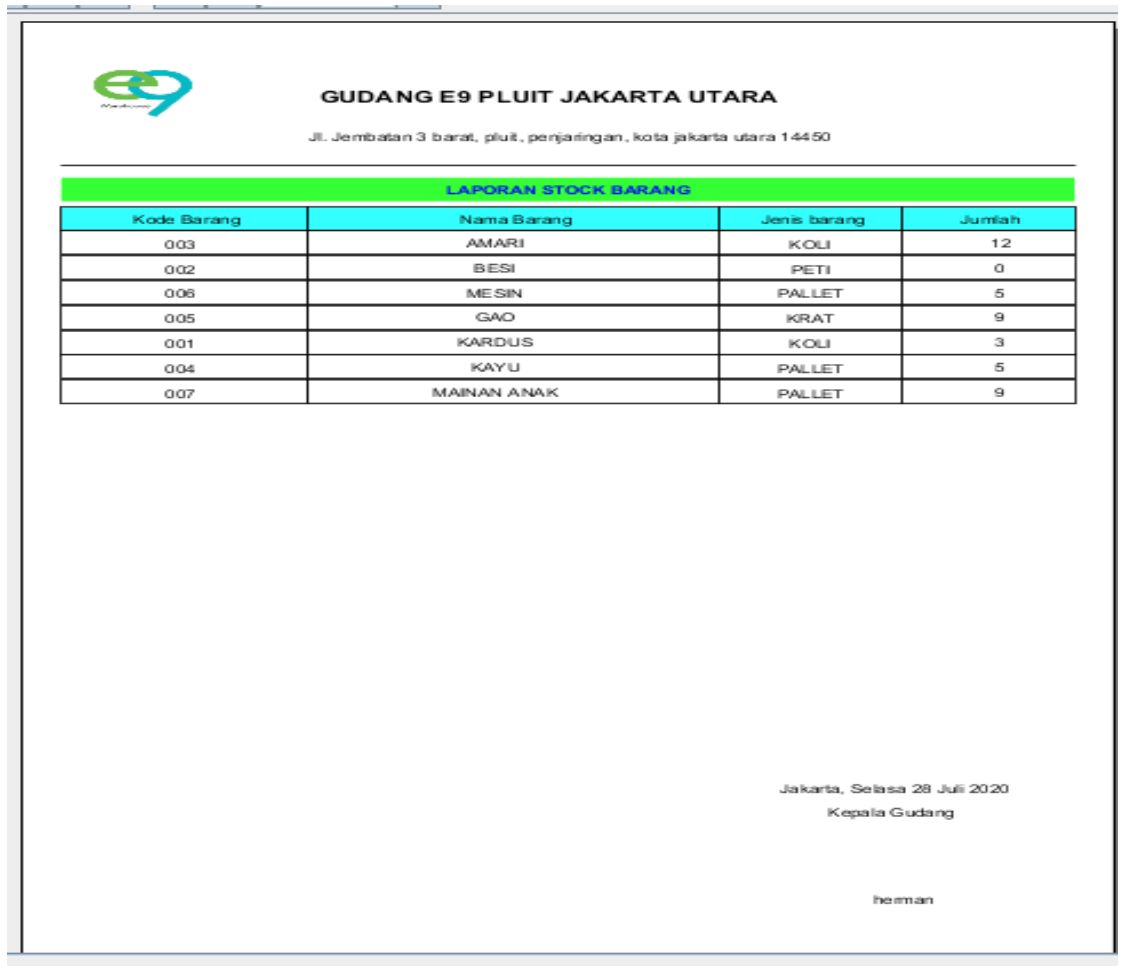

Gambar 6. Tampilan Laporan Stok Barang

Tampilan laporan stok barang ini merupakan tampilan laporan yang akan di print sebagai bukti transaksi terakhir.

\section{SIMPULAN}

Setelah menganalisis permasalahan-permasalahan yang ditemui di Gudang E9 Pluit Jakarta Utara dan penjelasan yang dikemukakan pada bab-bab sebelumnya maka dapat diambil kesimpulan sebagai berikut:

1. Dengan dihasilkanya sistem aplikasi stok barang Gudang E9 berbasis Java Netbeans ini. Maka sistem aplikasi ini mempermudah para pemesan barang dan dengan mudah mengetahui stok barang yang ada. Dan dapat meminimalisir kesalahan input pada Gudang E9 Pluit Jakarta Utara.

2. Dengan dihasilkanya sistem aplikasi stok barang Gudang E9 berbasis Java Netbeans ini. Dapat mempermudah karyawan dalam penginputan data maupun pencarian data.

3. Dengan dihasilkanya sistem aplikasi stok barang Gudang E9 berbasis Java Netbeans ini. Data yang dihasilkan lebih akurat dan efisien.

\section{DAFTAR PUSTAKA}

A.S., Rosa dan Shalahuddin, M. (2016). Rekayasa Perangkat Lunak Terstruktur dan Berorientasi Objek. In Informatika Bandung.

Ichwan, M. (2011). Pemrograman Basis data delphi 7 dan Mysql. Bandung: Informatika.

Indrajani, S. (2015). Database Design. Elex Media Komputindo.

Ismail, R. (2009). Metode Penelitian Kualitatif. USUpress.

Moh, N. (2013). Metode Penelitian. cetakan kedelapan Ghalia Indonesia. Bogor.

Nofriadi, J. F. D. N. (2015). 8.0. 2. Yogyakarta: DeePublish.

Pramana, H. W. (2012). Aplikasi Inventory Berbasis Access 2003. Jakarta: PT. Elex Media Komputindo.

Rosa, A. S., \& Shalauddin, M. (2011). Modul Pembelajaran Rekayasa Perangkat Lunak (Terstruktur dan Berorientasi Objek).

Sutabri, T. (2012). Analisis sistem informasi. Penerbit Andi.

Wicaksono, S. A., \& Samsoni, S. (2021). Perancangan Aplikasi Sistem Inventory Gudang Di Pt. Bank Tabungan Negara (Persero) Tbk Cabang Depok. Prosiding Seminar Informatika Dan Sistem Informasi, 5(3), 215-222. 